\title{
Neobvyklý útvar v pravé síni
}

\author{
David Štěrba, Rudolf Feuereisel, Petr Frídl \\ Kardiologie na Bulovce, s.r.o., Praha, Česká republika
}

Adresa: MUDr. David Štěrba, Kardiologie na Bulovce, s.r.o., Na Truhlářce 62, Praha 8, e-mail:dsterba@post.cz

Při nálezu útvaru v pravé síni se diferenciálně diagnosticky může jednat o Eustachovu chlopeň, Chiariho sítku, elektrody, katetry, zachycený embolus s jasně ohraničenou a pohyblivou strukturou či nádory. Primární nádory bývají nejčastěji histologicky benigní - myxom, lipom, hemangiom, výjimkou je vzácný angiosarkom. Maligní charakter mají převážně sekundární, prorůstající nádory - hypernefrom, hepatom, leiomyosarkom dělohy. Stěny pravé síně jsou predilekční lokalizací lymfomu a angiosarkomu. 


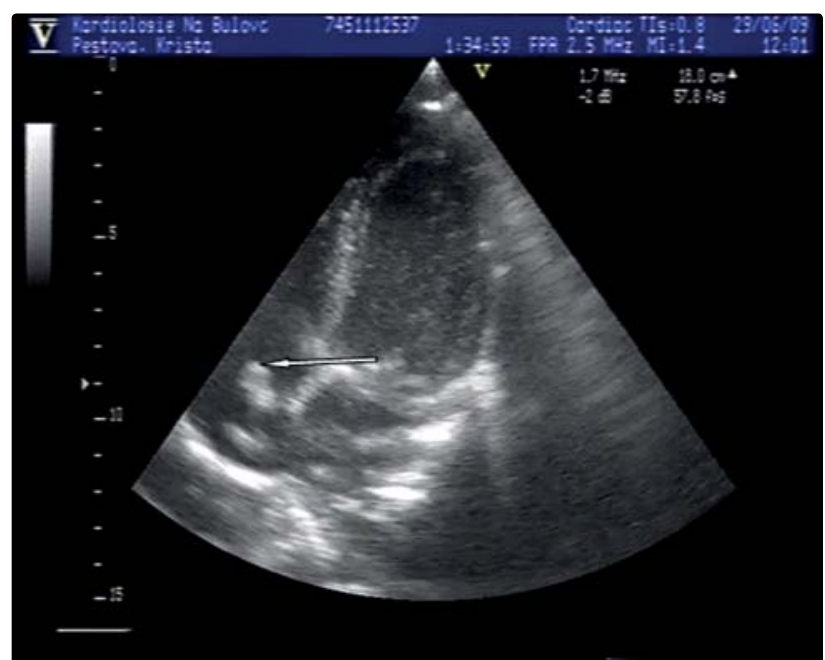

Obrázek 1 Apikální čtyřdutinová projekce

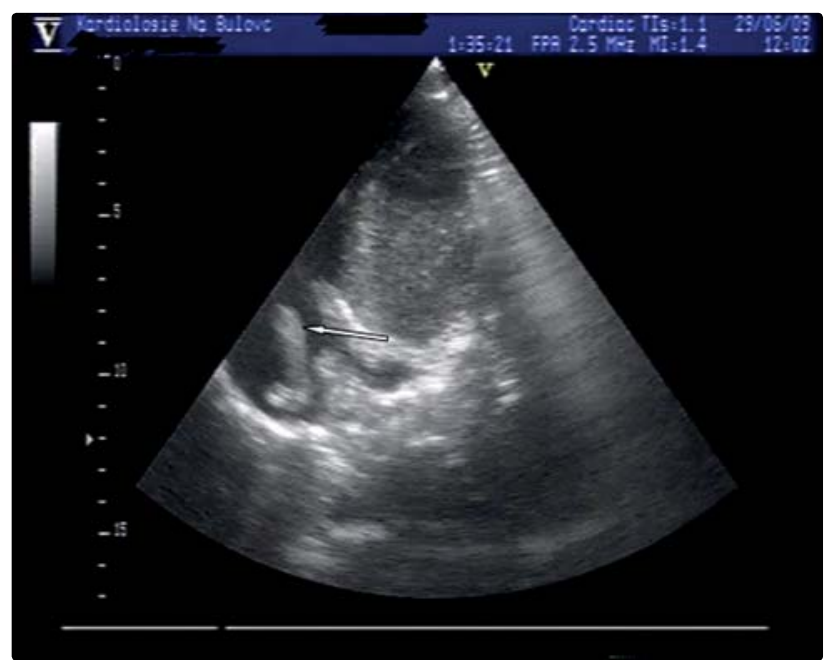

Obrázek 2 Apikální čtyřdutinová projekce

\section{Popis prípadu}

Pětatřicetiletá pacientka, kachektizující, s ascitem, anemií, alterací renálních funkcí, byla hospitalizována na infekční klinice pro generalizovanou aktinomykózu. Při CT vyšetření hrudníku byla zjištěna neobturující trombóza dolní duté žíly. Doplněným echokardiografickým vyšetřením byl v dolní duté žíle zjištěn neobturující útvar velikosti $10 \mathrm{~mm}$, v pravé síni nástěnně pokrývá $10 \mathrm{~mm}$ část stěny síně (obrázky 1-4). Dále byl prrítomen jeden výraznější výběžek $35 \times 10 \mathrm{~mm}$ (viz šipky) narážející na trikuspidální chlopeň. Velikost srdečních oddílů, kinetika i ejekční frakce obou komor byla v normě, bez přítomnosti chlopenní vady a perikardiálního

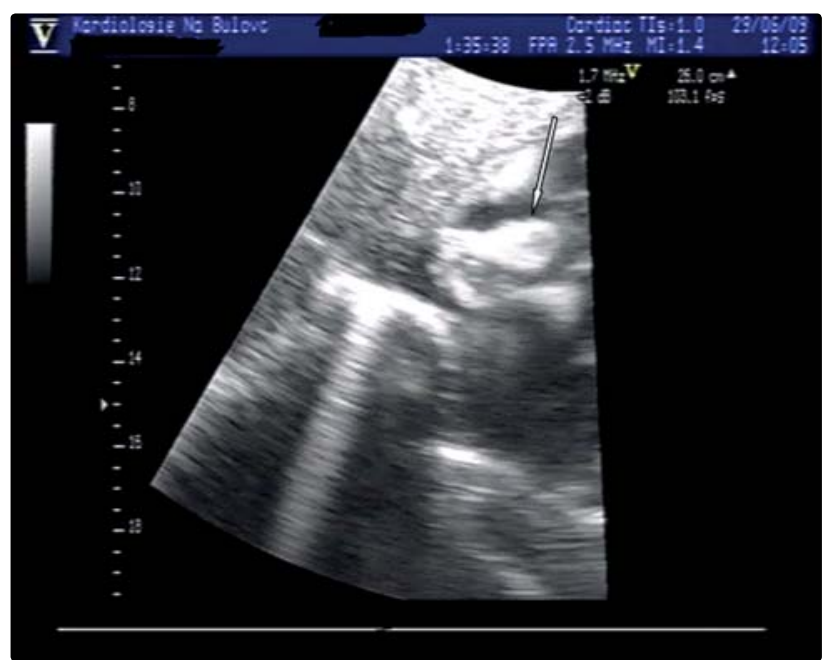

Obrázek 3 Subkostální projekce

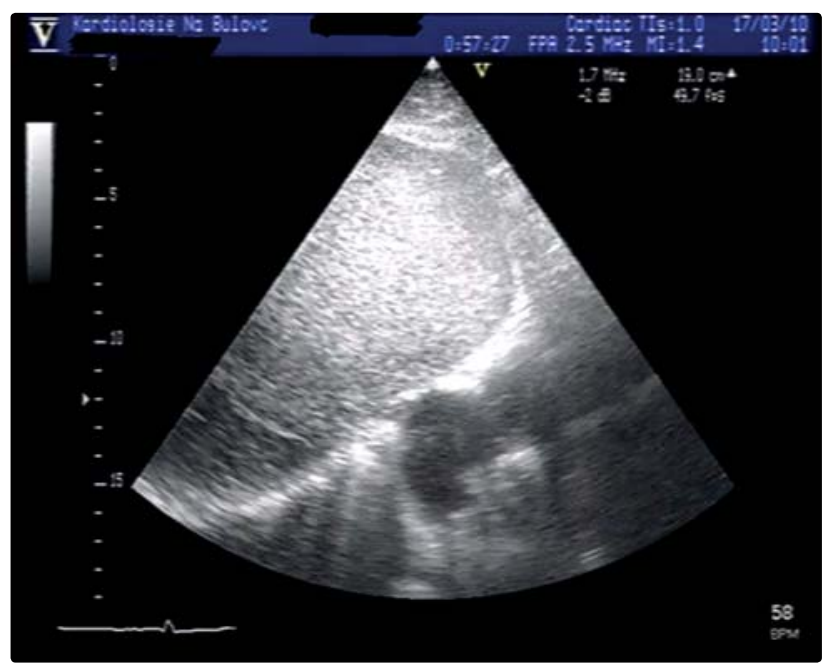

Obrázek 4 Subkostální projekce

výpotku. Při komplexní antibiotické a antikoagulační terapii došlo k postupné normalizaci nálezu v pravém srdci. Kontrolní echokardiografie s odstupem byla již bez reziduí patologických útvarů, které zpětně hodnotíme jako tromby.

\section{Literatura}

1. Toušek P, Krupička J, Riedel M. Nitrosrdeční útvary. Kardioforum 2004;4:6-12.

2. Linhart A, Paleček T, Aschermann M. Echokardiografie pro praxi. Praha: Toshiba, 2002:182-183.

Došlo do redakce: 20. 5. 2011

Prijato: 20. 10. 2011 